\title{
Próba interpretacji litogenetycznej osadów diamiktonowych w Kotlinie Orawskiej (Karpaty Zachodnie)
}

\author{
Attempt at lithogenetic interpretation of diamictic deposits in the Orava Basin (Western \\ Carphatians)
}

\author{
Dorota Chmielowska \\ Instytut Geografii, Uniwersytet Pedagogiczny im. Komisji Edukacji Narodowej w Krakowie; e-mail: dchmielo@up.krakow.pl
}

\begin{abstract}
Zarys treści: Pokrywą fluwioglacjalnych żwirów w terasach i stożkach Czarnego Dunajca w Kotlinie Orawskiej są osady gliniaste o miąższości 1-3 m. Ich geneza, cechy teksturalne i strukturalne są dotychczas bardzo słabo poznane. Niniejszy artykuł jest analizą jednej z cech tych osadów - ich uziarnienia. Przebadano 25 próbek tych osadów, pobranych z odsłonięć i wierceń, stosując graficzne wskaźniki uziarnienia opracowane przez Folka i Warda (1957). Wyniki analiz osadów wskazują, że na większości stanowisk badawczych uziarnienie glin różni się w małym zakresie. W profilach pokrywy gliniastej występuje lokalnie tendencja wzrostu ku stropowi udziału frakcji grubo pyłowych, maleje natomiast udział w tym kierunku frakcji piaskowej lub też uziarnienie jest jednorodne w całym profilu. W wierzchowinowych strefach stożków plejstoceńskich gliny mają masywną strukturę, na niższych terasach Czarnego Dunajca zaznacza się niewyraźne warstwowanie. Cechy uziarnienia badanych osadów nie rozstrzygają jednoznacznie o ich genezie, osady te wydają się być poligeniczne.
\end{abstract}

Słowa kluczowe: uziarnienie, osady gliniaste, stożki glacifluwialne, Kotlina Orawska

\begin{abstract}
The topmost part of gravelly fans and glacifluvial terraces of the Czarny Dunajec in the Orava Basin consists of 1-3 m thick layer of diamictic deposits. Their origin and structural and textural characteristics have not been so far well-recognized. This paper focuses on one of these characteristics i.e. grain-size. Samples of diamictic sediments were collected at 25 sites (natural outcrops, trenches, bore holes) and studied using graphic measures by Folk and Ward (1957). The results of the analysis indicate that grain-size of the sampled material is very similar. Locally, vertical profiles of the loamy cover shows a tendency to the upward increase in the proportion of coarse-grained silt with the concurrent decrease of sand; or the grain-size is similar in the entire profile. The proportion of clay in the loams is relatively small. Analyzed diamictons are massive in the hilltop sections of the Pleistocene fans, while on the terraces of the Czarny Dunajec River weakly pronounced layering occurs. The origin of the studied deposits cannot be unambiguously determined on the basis of their grain-size characteristics; in turn, the origin of the loams seems polygenetic.
\end{abstract}

Key words: grain-size composition, loamy deposits, glacifluvial terraces, Orava Basin

\section{Wprowadzenie}

Na północnym przedpolu Tatr znajdują się rozległe stożki żwirowe, utworzone przez Czarny i Biały Dunajec oraz Białkę Tatrzańską w kolejnych okresach zlodowacenia dolin tatrzańskich w plejstocenie. Zajmują one dziś większość dna Kotliny Orawsko-Nowotarskiej. Najbardziej rozległe stożki usypał Czarny Dunajec w Kotlinie Orawskiej. W budowie wewnętrznej wszystkich różnowieko- wych stożków występuje duża zmienność lateralna i wertykalna, tak w zakresie uziarnienia osadów, jak i struktur depozycyjnych (m.in. Halicki 1930, Klimaszewski 1967, Birkenmajer, Stuchlik 1975, Watycha 1973, 1977a, b, Baumgart-Kotarba 1983, 1991-92, Lindner 1994). Dominującym budulcem tych stożków są żwiry i gruboziarniste piaski pochodzenia tatrzańskiego (Halicki 1930, Watycha 1977a, b). Pokrywę wszystkich żwirowych stożków z plejstocenu tworzy warstwa osadów wielofrakcyjnych 
o miąższości 1-3 m (Watycha 1977a, b, Baumgart-Kotarba 1983, 1991-92). W Kotlinie Orawskiej nadbudowuje ona glacifluwialne żwiry niemal ciągłą pokrywą o niewyrównanej powierzchni, odróżniając się zdecydowanie od nich uziarnieniem i teksturą oraz maskując lateralny zasięg poszczególnych stożków żwirowych.

Osady wielofrakcyjne zalegające na powierzchni stożków plejstoceńskich w Kotlinie Orawskiej są powszechnie nazywane w literaturze ,glinami” (Watycha 1977a, b, Baumgart-Kotarba 1991-92, Birkenmajer i in. 2008). W świetle poniższych analiz nie klasyfikują się one jednak do grupy typowych glin (diamiktonów). Ponieważ jednak w ocenie makroskopowej i w powszechnym użyciu przyjmuje się dla nich określenie „osady gliniaste”; autorka zastosuje tą nazwę także w dalszej części artykułu.

Osady gliniaste nie były dotąd przedmiotem kompleksowych badań, stąd ich geneza nie jest jednoznacznie ustalona. Jedynie lokalnie badano ich strukturę, wapnistość oraz wiek osadów (Watycha 1973, Baumgart-Kotarba 1991-92, Birkenmajer 1978). Poglądy na ich genezę są podzielone (Watycha 1976, 1977a, b, Baumgart-Kotarba 1991-92, Birkenmajer 1978, Birkenmajer i in. 2008) i nie poparte wynikami kompleksowych badań. Mogą być one wieku plejstoceńskiego, a nawet holoceńskiego, na co wskazują wyniki datowań metodą TL dwóch próbek gliny z rejonu Chyżnego (146 $\pm 40 \mathrm{Ka}$ i $110 \pm 15 \mathrm{Ka}$ ) (Baumgart-Kotarba 1991-1992). Górną granicę wieku badanych osadów może lokalnie wyznaczać konwencjonalny wiek radiowęglowy spągowych warstw torfu (najstarsze
- 8960 \pm 80 BP; Obidowicz 1988, 1990), z torfowisk powstałych na analizowanych osadach.

Głównym celem tego artykułu jest przedstawienie wyników analizy uziarnienia osadów gliniastych w obrębie Kotlinie Orawskiej. Na podstawie tych wyników starano się ustalić prawdopodobną genezę glin. Zbadanie glin na dużej przestrzeni stożków wydaje się celowe, gdyż porównanie ich uziarnienia $w$ wielu oddalonych od siebie miejscach może uczynić pewniejszą interpretację pochodzenia tych glin. Znajdują się one w dnie kotliny śródgórskiej, gdzie zwykle deponowane są materiały allochtoniczne, jednak jak wskazują autorskie badania nie są to typowe osady eoliczne, fluwialne, jak sugerowano w licznych publikacjach. Być może w ich powstaniu uczestniczył aktywnie także czynnik działający we wszystkich obszarach i strefach klimatycznych, jakim jest wietrzenie (Wright 2007).

\section{Obszar badań}

Kotlina Orawska jest zachodnią częścią śródgórskiej Kotliny Orawsko-Nowotarskiej (Kondracki 2000). Od północy graniczy ona z Działami Orawskimi i Beskidem Wysokim, natomiast południową granicę tworzą pasma Magury Orawskiej, Pienin oraz Pogórza: Skoruszyńskie i Gubałowsko-Spiskie (Klimaszewski 1972, Książkiewicz 1972) (ryc. 1). Ma ona ok. 40 km długości o rozciągłości równoleżnikowej i 3-15 km szerokości. Jej dno jest łagodnie nachylone $\left(3-5^{\circ}\right)$ ku północy od wysokości 770-760 m n.p.m. w rejonie Chochołowa - Suchej Hory

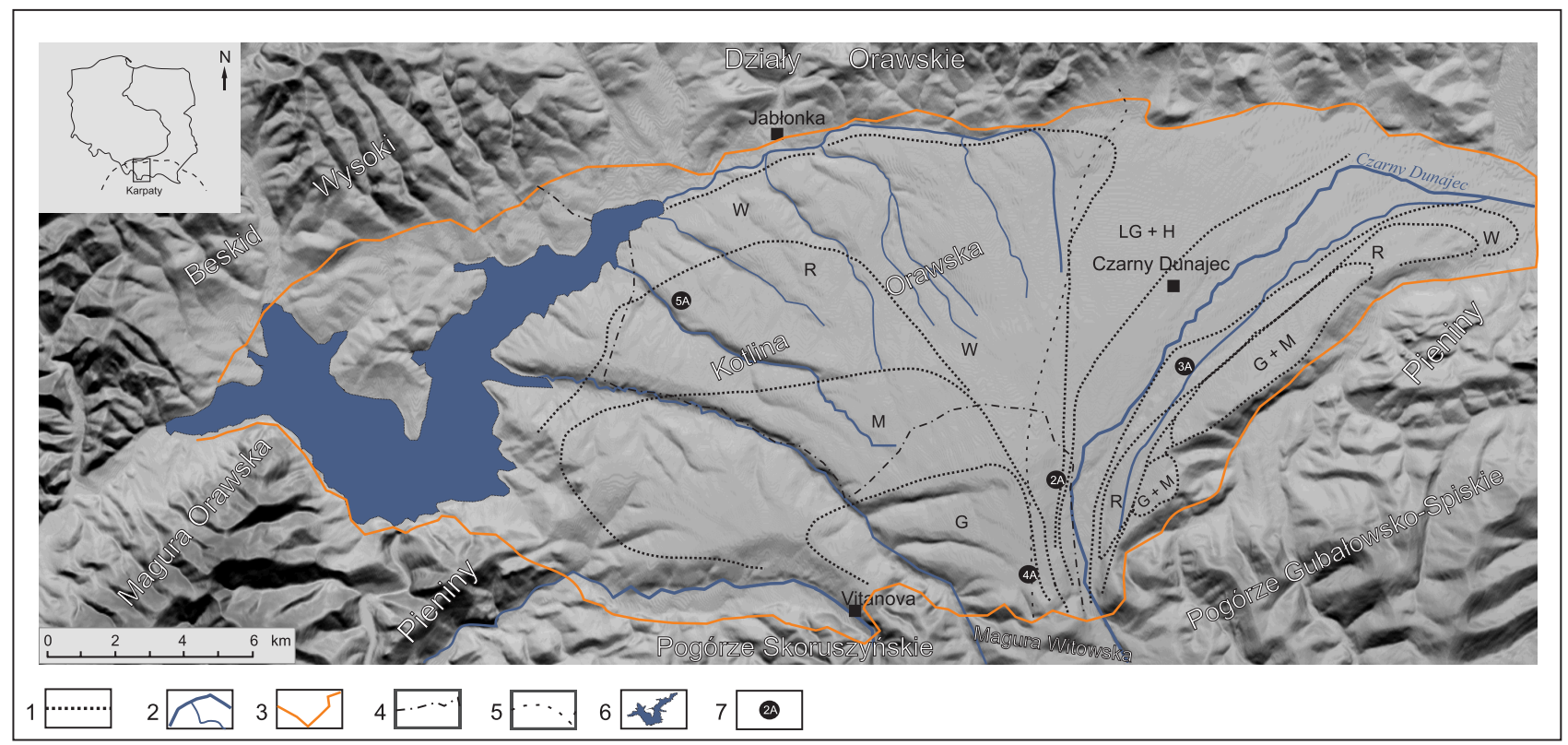

Ryc. 1. Położenie wybranych stanowisk badawczych na tle układu stożków fluwioglacjalnych w Kotlinie Orawskiej

1 - zasięg stożków fluwioglacjalnych (G - Günz; M - Mindel; R - Riss; W - Würm; LG - późny glacjał i holocen) według Watychy (1977a, b) i Baumgart-Kotarby (1991-1992), uzupełnione); 2 - rzeki, potoki; 3 - granica dna Kotliny Orawskiej; 4 - granica państwa 5 - europejski dział wodny; 6 - Zbiornik Orawski; 7 - stanowiska badawcze

Fig. 1. Location of study sites on glacifluvial terraces and fans in the Orava Basin

1 - the extent of glacifluvial terraces and fans after Watycha (1977a, b) and Baumgart-Kotarba (1991-92) (G - Günz; M - Mindel; R - Riss; W - Würm; LG+H - Late Glacial and Holocene); 2 -rivers, stremas; 3 - border of the Orava Basin bottom; 4 - state border; 5 - European watershed; 6 - Orawski Reservoir; 7 - study sites 
do 620-600 m n.p.m. w rejonie Lipnicy Wielkiej - Ludźmierza. W rzeźbie Kotliny wyróżnia się jej część zachodnia, w której dominują powierzchniowo starsze elementy rzeźby oraz część wschodnia - z przewagą form holoceńskich. Rzeźbę zachodniej części Kotliny tworzą płaskie, rozległe stożki i terasy plejstoceńskie Czarnego Dunajca z okresów Günz, Mindel, Riss i Würm, a więc z okresu gdy wody tej rzeki przepływały w kierunku zachodnim (do Orawy i dalej do Wagu). Badana pokrywa osadów gliniastych zalega tylko na powierzchni tych czterech stożków. Starsze stożki w tej części Kotliny są rozcięte dolinami o głębokości do 40 m (Baumgart-Kotarba 1991-92). Wielkość rozcięcia rośnie ku zachodowi Kotliny i nawiązuje do spadku doliny Czarnej Orawy. W tej części występują trzy poziomy stożków: I - o wysokości 660-680 m, II - 640-650 m, III - 635 m i 610-615 m n.p.m. (Baumgart-Kotarba 1991-92). Nawiązują one do systemu teras skalno-osadowych w wyższym biegu Czarnego Dunajca (Pogórze Gubałowskie). Poziomy stożków są rozdzielone mało wyraźnymi załomami terenu (o nachyleniu 3-6 ${ }^{\circ}$ ).

Część wschodnią Kotliny zajmuje późnoglacjalny stożek Czarnego Dunajca o promieniu 10-12 km. Jego spadek w górnej części wynosi 12,5\%o, a w dolnej 10,2\%o (Baumgart-Kotarba 1991-92). Na jego powierzchni znajdują się dobrze zachowane ślady rynien i koryt roztokowych. Stożek rozcięty jest dolinami o głębokości 5-11 m. W rzeźbie tej części Kotliny występują jeszcze 2-3 poziomy niskich teras Czarnego Dunajca. Na stożkach i terasach holoceńskich Czarnego Dunajca, płynącego w kierunku wschodnim (na odcinku od miejscowości Czarny Dunajec do przełomu pienińskiego i dalej do Wisły) pokrywa gliniasta nie występuje (Watycha 1977a, b, Baumgart-Kotarba 1991-92).

W dnie Kotliny Orawskiej zalegają słodkowodne osady neogeńskie, głównie iły, piaski i fliszowe żwiry (Watycha 1973, 1976). Przykryte są one osadami czwartorzędowymi, pochodzenia wodnolodowcowego, facji rzecznej i zastoiskowej, należące do rozległego stożka napływowego Czarnego Dunajca (Watycha 1973, 1976, 1977a, b). Materiałem budującym poszczególne stożki napływowe i holoceńskie terasy Czarnego Dunajca są otoczaki z granitoidów, gnejsów, amfibolitów, łupków krystalicznych i mikowych. Dopełnieniem składu petrograficznego są otoczaki tatrzańskich piaskowców kwarcytowych, wapieni i dolomitów (Watycha 1977a, b). Wraz z odległością od Tatr i wiekiem każdej z teras zmienia się udział poszczególnych litotypów.

W pokrywie najstarszej (Günz, Mindel) dominują otoczaki kwarcytowe (40-100\% składu żwiru) upakowane w grubym piasku (Halicki 1930, Watycha 1977a, b, Kukulak 1997). Mniej liczne otoczaki granitowe, gnejsowe i łyszczykowe są tak silnie zwietrzałe, że łatwo ulegają rozpadowi na glinę i piasek kwarcowo-skaleniowo-łyszczykowy o barwie ochrowej (Watycha 1977a, b). Miąższość tej pokrywy jest przestrzennie różna, przeważnie ma 2-4 m, ale lokalnie nawet do $15 \mathrm{~m}$. W pokrywie risskiej o miąższości od 3 do $10 \mathrm{~m}$ udział kwarcytów w maleje (15-30\%) na korzyść granitów, które są mniej zwietrzałe niż w pokrywie starszej (Kukulak 1997). Natomiast pokrywa würmska zbudowana jest głównie ze skał granitowych, gnejsowych (60\%), z łupków krystalicznych i z kwarcytów (10-12\%), a także z wapieni, dolomitów i piaskowców z fliszu podhalańskiego. Miąższość tych osadów w wynosi od 5 do10 m w części południowej, natomiast wzrasta do 26 m w części północnej (Watycha 1977a, b).

Do badań osadów gliniastych wytypowano cztery stanowiska położone na stożkach i terasach plejstoceńskich Czarnego Dunajca, usytuowanych w różnej odległości od dzisiejszego koryta tej rzeki (ryc. 1). Dwa stanowiska (Chochołów i Czarny Potok), położone bliżej koryta, są naturalnymi odsłonięciami (podcięcia erozyjne brzegów Czarnego Dunajca) budowy terasy würmskiej (Watycha 1977a, b, Baumgart-Kotarba 1991-92). Dwa pozostałe (Sucha Hora i Chyżne) dokumentują budowę pokrywy najstarszych stożków (pochodzących z okresów Günz, Mindel, Riss), w miejscach znacznie oddalonych od jego koryta i położonych na kulminacjach rozległych garbów międzydolinnych, wyciętych przez potoki w płaskiej powierzchni stożków. Wydzielenia wiekowe stożków przyjęto według prac Watychy (1977a, b) i Baumgart-Kotarby (1991-92) jedynie modyfikując lokalnie zasięg tych stożków. Szczegółową lokalizację miejsc badawczych umieszczono na rycinach 2A, 3A, 4A, 5A.

\section{Metody badań}

Badania osadów gliniastych Kotliny Orawskiej obejmowały prace terenowe i analizy laboratoryjne. W ramach badan terenowych wykonano w osadach jedno wiercenie (Sucha Hora) i oprofilowano trzy ich odkrywki. Bezpośrednio w profilach wiercenia i odsłonięć dokonano pomiarów miąższości osadów, rejestracji głębokości na jakich występują gliny o widocznym warstwowaniu, wykonano makroskopową identyfikację cech strukturalnych i tekstualnych osadów, pomiary średnicy megaklastów, a także wykonano dokumentację fotograficzną badanych odsłonięć. Z profilu glin (poniżej warstwy gleby) na każdym stanowisku badawczym pobrano materiał do analiz laboratoryjnych w odstępach co 10-20 cm (łącznie 25 próbek).

Analizę uziarnienia badanych osadów wykonano laboratoryjnie metodą kombinowaną (Mycielska-Dowgiałło 2007). Dla ziaren o średnicy większej niż $0,063 \mathrm{~mm}$ zastosowano metodę sitową, natomiast ziarna mniejsze niż 0,063 mm zmierzono za pomocą laserowego miernika

Tabela 1. Kod litotypów wg Szmańdy (2011) i litofacji według Zielińskiego i Pisarskiej-Jamroży (2012)

Table 1. Code of lithotypes after Szmańda (2011) and lithofacies after Zieliński and Pisarska-Jamroży (2012)

\begin{tabular}{ll}
\hline \multicolumn{1}{c}{ Nazwa osadu } & Kod \\
\hline Mułek żwirowy & FsG \\
Mułek żwirowy masywny & FsGm \\
Mułek żwirowy laminowany & FsGl \\
Mułek żwirowo-piaszczysty laminowany & FsGSl \\
Żwir piaszczysty masywny & GSm \\
\hline
\end{tabular}


cząstek Analysette 22 firmy Fritsch. Uzyskano wyniki pomiarów w przedziałach co 0,5 phi. Typ osadów oznaczono na podstawie programu Gradistat (Blott, Pye 2001), natomiast dla odróżnienia frakcji pylastej od ilastej we frakcji drobnoklastycznej przyjęto kod litotypu zaproponowany przez Szmańdę (2011) i litofacji według Zielińskiego i Pisarskiej-Jamroży (2012) (tab. 1).

Rozkład uziarnienia badanych osadów przedstawiono za pomocą krzywych kumulacyjnych uziarnienia w skali prawdopodobieństwa. Stosując wzory graficzne Folka i Warda (1957) obliczono wartości parametrów statystycznych. Wskaźniki te stały się podstawą opisu cech uziarnienia badanych osadów, a ich szczegółowy rozkład przedstawiono $\mathrm{w}$ tabeli 2 . Ponadto sporządzono diagram wzajemnej relacji średniej średnicy ziarna $(\mathrm{Mz})$ i wysortowania $\left(\sigma_{1}\right)$ badanych osadów w celu określenia relacji między uziarnieniem a warunkami transportu i środowiskiem sedymentacyjnym.

\section{Charakterystyka osadów gliniastych}

\section{Stanowisko Chochołów}

Stanowisko to znajduje się w północnej części miejscowości Chochołów (ryc. 2A), na erozyjnym podcięciu tera- sy würmskiej przez rzekę Czarny Dunajec. Warstwa osadów gliniastych o miąższości 2 m przykrywa tam żwiry w skalno-osadowej terasie o wysokości 9,5 m. Stok terasy jest w tym miejscu osuwiskowy, a odsłonięta warstwa glin należy do najbardziej redukowanych części tego stoku przez procesy grawitacyjne i mrozowe (Augustowski i in. 2013). Granica osadów gliniastych z niżej zalegającymi żwirami jest przejściowa. Badane osady pod względem cech tekstualnych są słabo zróżnicowane, natomiast pod względem strukturalnym cechują się słabo zaznaczającą się laminacją horyzontalną. W odróżnieniu od glin na pozostałych stanowiskach mają one zabarwienie jasnoszare i jasnopopielate (ryc. 2B). Ponadto, w przypowierzchniowej części stoku występuje w glinach gęsta sieć szczelin pionowych i spękań poziomych. Wzdłuż tych szczelin oraz w kanalikach po korzeniach roślin występują konkrecje żelaziste w formie pieprzy. W warstwie osadów o charakterze diamiktonowym występują także pojedyncze otoczaki granitowe, zwłaszcza w jej dolnej części.

Analiza uziarnienia próbek osadów gliniastych $\mathrm{z}$ tego stanowiska wykazała, że w tym profilu dominuje frakcja pylasta. Do głębokości $70 \mathrm{~cm}$ jest to mułek żwirowy $\left(\mathrm{F}^{\mathrm{s}} \mathrm{Gl}\right)$, natomiast od $71 \mathrm{~cm}$ do $190 \mathrm{~cm}$ zalega mułek żwirowo-piaszczysty $\left(\mathrm{F}^{\mathrm{s}} \mathrm{GSl}\right)$ (ryc. $2 \mathrm{C}$ ). W badanym profilu ponad połowę składu osadów stanowi frakcja pylasta. Jej przecięty udział wynosi $66 \%$, frakcji piaszczystej jest

Tabela 2. Statystyczne parametry uziarnienia badanych osadów gliniastych w wybranych stanowiskach badawczych w Kotlinie Orawskiej $\mathrm{Mz}$ - średnia średnica ziarna (phi); $\sigma_{1}$ - wysortowanie; $\mathrm{S}_{\mathrm{K}}$ - skośność; $\mathrm{K}_{\mathrm{G}}-$ kurtoza

Table 2. Statistical grain-size parameters of diamictic deposits in study sites in the Orava Basin $\mathrm{Mz}$ - mean grain size (phi); $\sigma_{1}$ - sorting coefficient; $\mathrm{S}_{\mathrm{K}}$ - skeweness; $\mathrm{K}_{\mathrm{G}}$ - curtosis

\begin{tabular}{|c|c|c|c|c|c|c|}
\hline Stanowisko badawcze & Numer próbki & Głębokość [cm] & $\mathrm{Mz}$ & $\sigma 1$ & Sk & $\mathrm{KG}$ \\
\hline \multirow[t]{9}{*}{ Chochołów } & 1 & 20 & 5,8 & 1,6 & $-0,3$ & 1,4 \\
\hline & 2 & 40 & 5,1 & 3,1 & 0,3 & 1,5 \\
\hline & 3 & 60 & 6,4 & 1,6 & $-0,2$ & 1,0 \\
\hline & 4 & 80 & 5,1 & 3,4 & 0,4 & 0,9 \\
\hline & 5 & 110 & 5,3 & 2,8 & 0,2 & 1,1 \\
\hline & 6 & 130 & 5,2 & 3,2 & 0,3 & 1,0 \\
\hline & 7 & 150 & 4,7 & 3,4 & 0,2 & 0,8 \\
\hline & 8 & 170 & 3,9 & 4,0 & 0,3 & 1,0 \\
\hline & 9 & 190 & 3,7 & 3,8 & 0,2 & 0,8 \\
\hline \multirow[t]{4}{*}{ Czarny Potok } & 1 & 45 & 6,3 & 1,8 & 0,2 & 1,2 \\
\hline & 2 & 70 & 6,2 & 1,8 & 0,2 & 1,0 \\
\hline & 3 & 100 & 5,8 & 1,7 & 0,3 & 1,3 \\
\hline & 4 & 120 & 6,0 & 2,1 & 0,1 & 1,5 \\
\hline \multirow[t]{8}{*}{ Sucha Hora } & 1 & $20-30$ & 6,1 & 1,9 & 0,2 & 1,2 \\
\hline & 2 & $30-40$ & 6,1 & 1,9 & 0,2 & 1,2 \\
\hline & 3 & $40-50$ & 6,1 & 1,8 & 0,2 & 1,1 \\
\hline & 4 & $50-60$ & 6,2 & 1,9 & 0,2 & 1,0 \\
\hline & 5 & $60-70$ & 6,2 & 1,9 & 0,2 & 1,0 \\
\hline & 6 & $70-75$ & 6,1 & 2,2 & 0,2 & 1,1 \\
\hline & 7 & $75-85$ & 6,3 & 2,0 & 0,1 & 1,1 \\
\hline & 8 & $85-88$ & 6,2 & 2,0 & 0,1 & 1,1 \\
\hline \multirow[t]{4}{*}{ Chyżne } & 1 & 8 & 4,3 & 2,9 & $-0,3$ & 1,2 \\
\hline & 2 & 15 & 3,1 & 3,5 & $-0,3$ & 0,8 \\
\hline & 3 & 24 & 4,4 & 3,3 & $-0,2$ & 0,9 \\
\hline & 4 & 35 & 4,3 & 3,0 & $-0,2$ & 1,1 \\
\hline
\end{tabular}



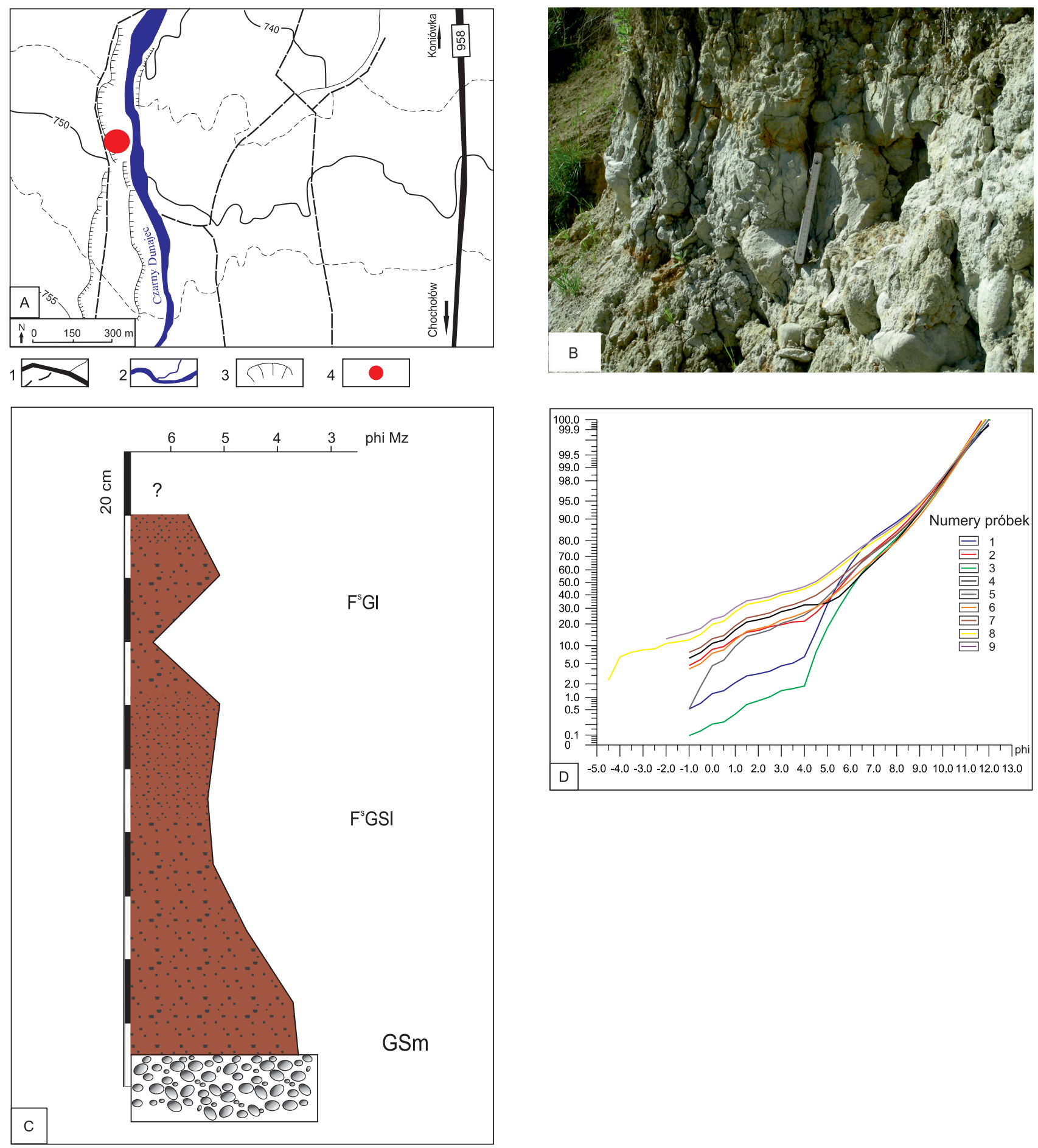

Ryc. 2. Lokalizacja stanowiska Chochołów (A) i profil badanych osadów (B) oraz profil litofacjalny osadów w tym stanowisku (C) i ich krzywe kumulacyjne uziarnienia (D)

1 - drogi; 2 - rzeki; 3 - skarpy; 4 - stanowisko badawcze

Fig. 2. Location of the Chochołów site (A) and outcrop of study diamictions (B) and lithofacial profile of study deposit in study site (C) and their grain size composition cumulative curves (D)

1 - roads; 2 - rivers; 3 - scarp, undercut; 4 - study site

$21 \%$, frakcji ilastej 7\%, a frakcji żwirowej 6\% (ryc. 2D). Analizowane osady wielofrakcyjne cechują się słabym lub bardzo słabym wysortowaniem i mają rozkłady mezo- lub platykurtyczne. Rozkłady uziarnienia w większości próbek (80\%) są dodatnio skośne i wielomodalne. Wysortowanie pogarsza się wraz ze zwiększającą się wartością średniej średnicy ziarna (Mz), które rosną z głębokością (tab. 2).

\section{Stanowisko Czarny Potok}

Stanowisko Czarny Potok znajduje się w odległości ok. 1 km na wschód od miejscowości Podczerwone (ryc. 3A). Badane osady odsłaniają się w erozyjnym podcięciu lewego brzegu Czarnego Potoku (prawoboczny dopływ Czarnego Dunajca). Potok ten wcina się w płaską powierzchnię 

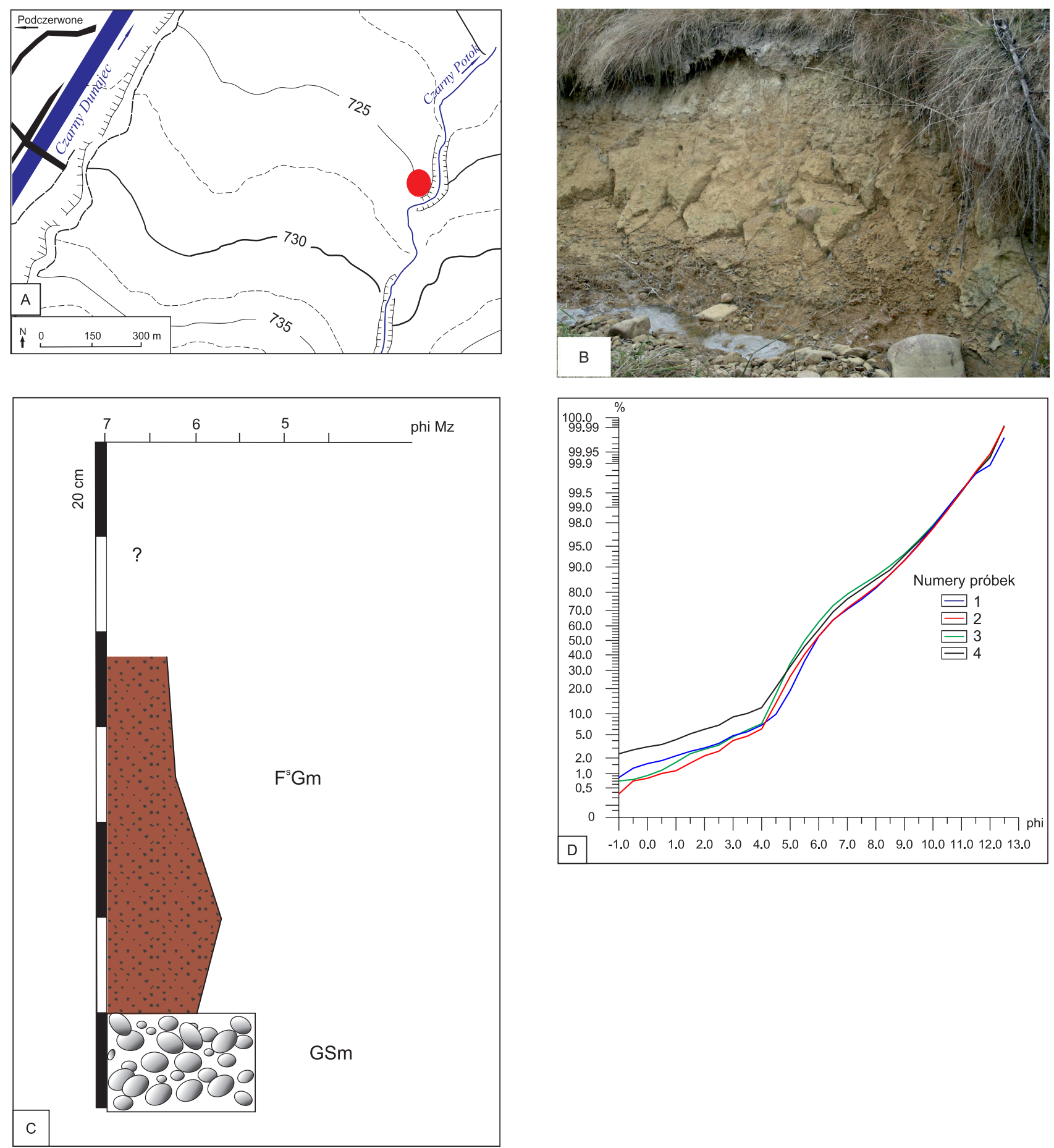

Ryc. 3. Lokalizacja stanowiska Czarny Potok (A) i profil badanych osadów (B) oraz profil litofacjalny osadów w tym stanowisku (C) oraz ich krzywe kumulacyjne uziarnienia (D). Objaśnienia na ryc. 2A

Fig. 3. Location of the Czarny Potok site (A) and outcrop of study diamictions (B) and lithofacial profile of study deposit in study site (C) and their grain size composition cumulative curves (D). Explanation in the fig. $2 \mathrm{~A}$

terasy würmskiej na głębokość 1,2-1,7 m. Poziom tej terasy wznosi się 15-17 m nad korytem Czarnego Dunajca. Odsłonięte osady gliniaste mają na tym stanowisku miąższość 1,40 m i jest widoczny ich kontakt $\mathrm{z}$ niżej zalegającymi żwirami terasy. Badane osady są makroskopowo jednorodne, charakteryzują się masywną strukturą. Posiadają ciemnobrązową barwę, są słabo zawilgocone i dość gęsto spękane pionowo (ryc. 3B). Na powierzchniach spękań występują koncentracje związków żelazistych. W dolnej części odsłoniętych osadów występują pojedynczo otoczaki kwarcytowe. Przejście w niżej zalegające żwiry jest stopniowe, nie ma ono charakteru erozyjnego.

Z wykonanych analiz uziarnienia osadów gliniastych wynika, że w profilu Czarny Potok, podobnie jak w Chochołowie, zalega głównie mułek żwirowy ( $\left.\mathrm{F}^{\mathrm{s}} \mathrm{Gm}\right)$ (ryc. 3C). Frakcją dominującą w badanym profilu jest frakcja pylasta. Jej przeciętny udział wynosi $85 \%$, frakcji piaszczystej jest 7\%, frakcji ilastej 7\%, a frakcji żwirowej jest 
tylko $1 \%$ (ryc. 3D). Rozkłady uziarnienia są mezo- lub leptokurtyczne. Badany osad jest generalnie słabo wysortowany, a jego wysortowanie systematycznie maleje wraz z głębokością od powierzchni terasy (tab. 2). Ponadto w osadzie słabo zaznacza się normalne uziarnienie frakcjonalne. Rozkłady uziarnienia są dodatnio skośne lub symetryczne. Osady z profilu Czarny Potok posiadają rozkłady jedno-, dwu- lub wielomodalne.

\section{Stanowisko Sucha Hora}

W Suchej Horze materiał do badań analitycznych uzyskano z wiercenia, założonego na płaskiej wierzchowinie wododzielnego garbu między Jeleśnią Wodą a Czarnym Dunajcem, na wysokości 760 m n.p.m. (ryc. 4A).
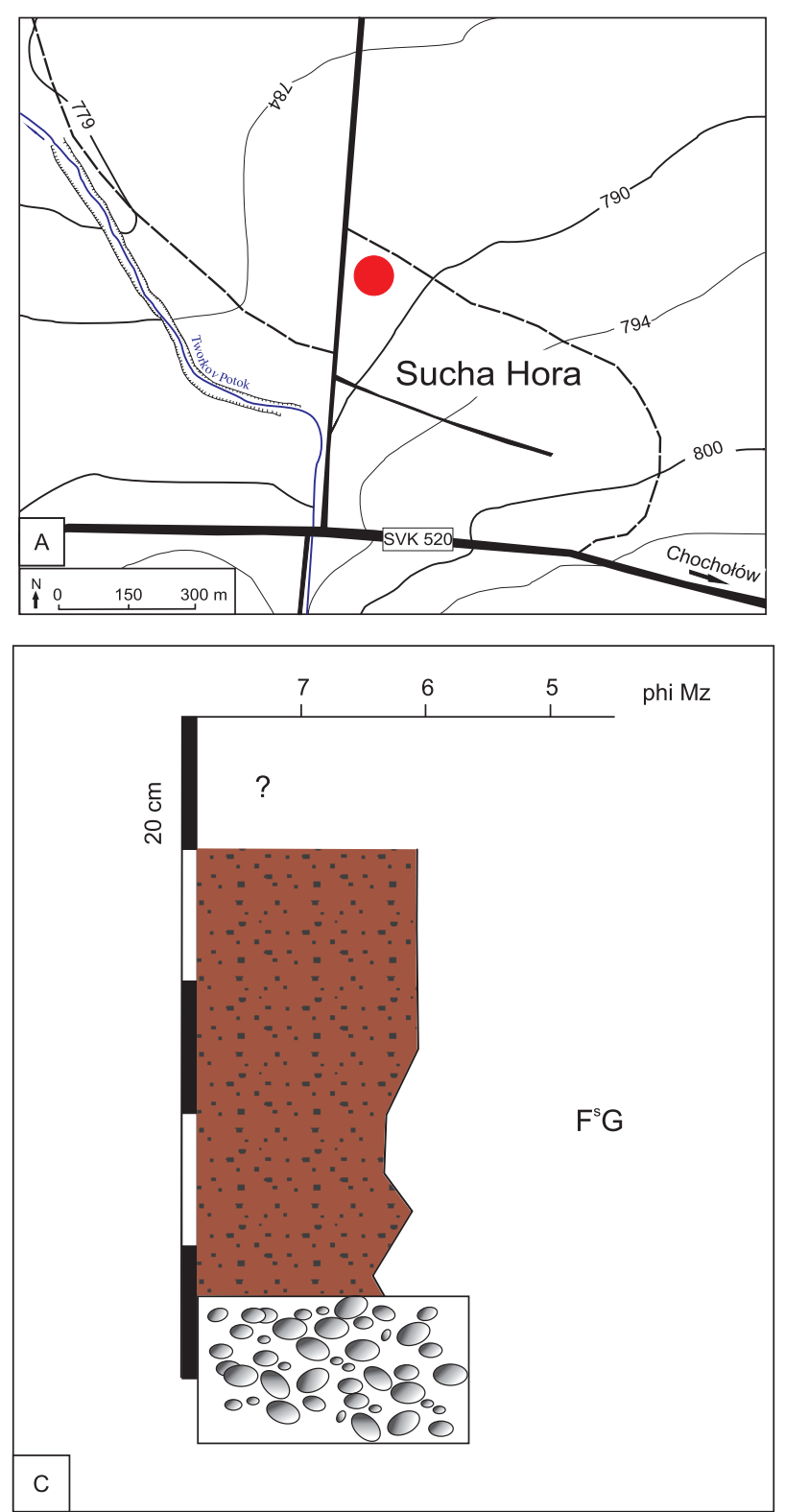

Wierzchowina tego garbu stanowi najwyższy i zarazem najstarszy fragment stożków Czarnego Dunajca (Günz). Przewiercono osady gliniaste do głębokości $90 \mathrm{~cm}$, nie sięgając ich spągu. Badania terenowe wskazują, że w profilu Sucha Hora osady gliniaste są tłuste, mułkowe z nieznaczną domieszką żwiru i piasku, o strukturze agregatowej. Charakteryzują się one ciemnobrązowym zabarwieniem i dużym zawilgoceniem, występują w nich konkrecje żelazisto-manganowe (ryc. 4B).

Analiza uziarnienia tych osadów wykazała, że są to mułki żwirowe $\left(\mathrm{F}^{\mathrm{s}} \mathrm{G}\right)$ (ryc. $4 \mathrm{C}$ ). Dominuje w nich frakcja pylasta. Jej przeciętny udział wynosi $84 \%$, frakcji ilastej jest 9\%, a frakcji piaszczystej 7\% (ryc. 4D). Analiza tekstury w pobranych próbkach osadów nie wykazała dużego zróżnicowania w całym profilu Sucha Hora, ponieważ

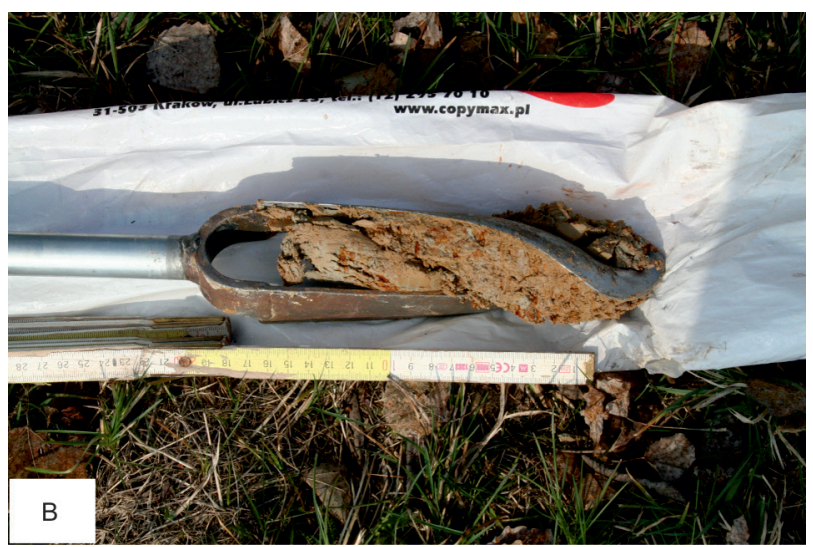

średnia średnica ziarna ma w nich podobną wartość. Osa-

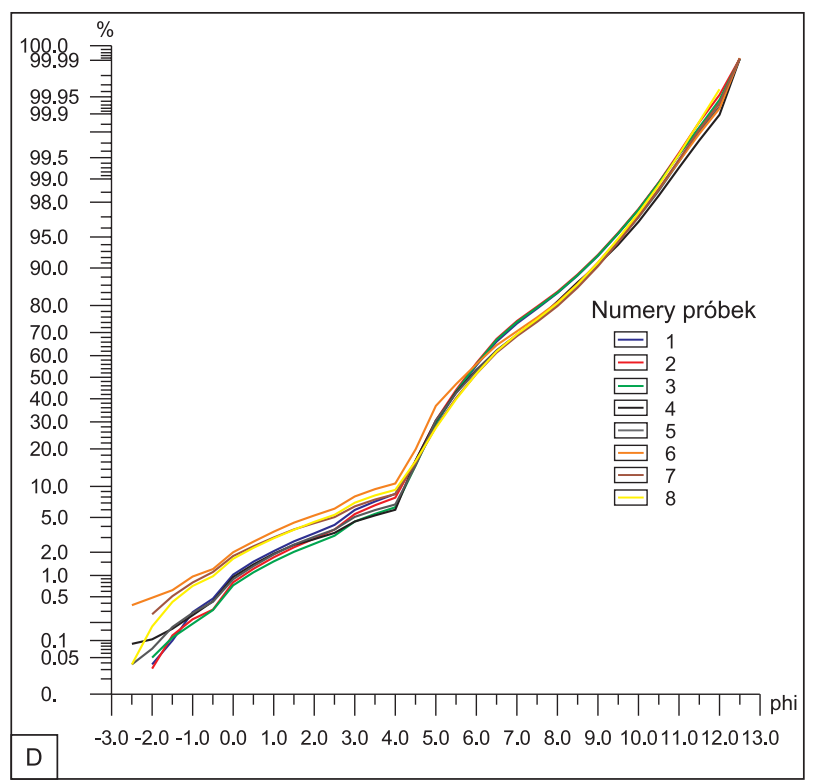

Ryc. 4. Lokalizacja stanowiska Sucha Hora (A) i profil badanych osadów (B) oraz profil litofacjalny osadów w tym stanowisku (C) oraz ich krzywe kumulacyjne uziarnienia (D) Objaśnienia na ryc. 2A

Fig. 4. Location of the Sucha Hora site (A) and outcrop of study diamictions (B)and lithofacial profile of study deposit in study site (C) and their grain size composition cumulative curves (D). Explanation in the fig. 2A 
dy diamiktonowe są słabo wysortowane i mają lepto- lub mezokurtyczne rozkład uziarnienia. Nieznacznie lepiej wysortowane jest osad w górnej części profilu - do głębokości $65 \mathrm{~cm}$. Rozkład uziarnienia jest dodatnio skośny lub symetryczny.
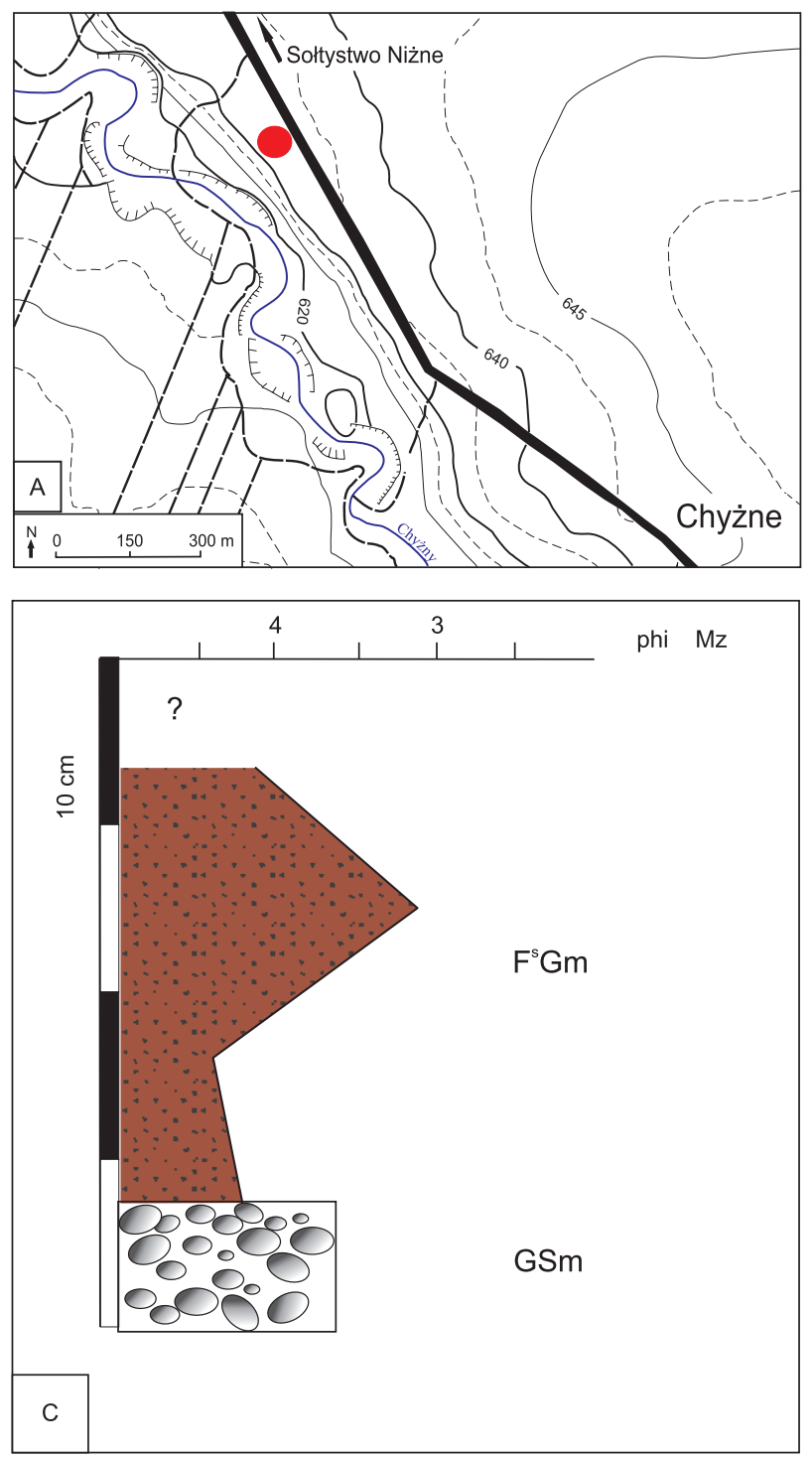

\section{Stanowisko Chyżne}

Stanowisko Chyżne znajduje się na wysokości $618 \mathrm{~m}$ n.p.m., na wododzielnym garbie w poziomie risskim, w miejscowości Chyżne (ryc. 5A). Wierzchowina tego garbu wznosi się 20-25 m nad korytem potoku Chyżny (dopływ Czarnej Orawy). W sztucznym wykopie odsłonięte są osady wielofrakcyjne o miąższości do $2 \mathrm{~m}$. Ich
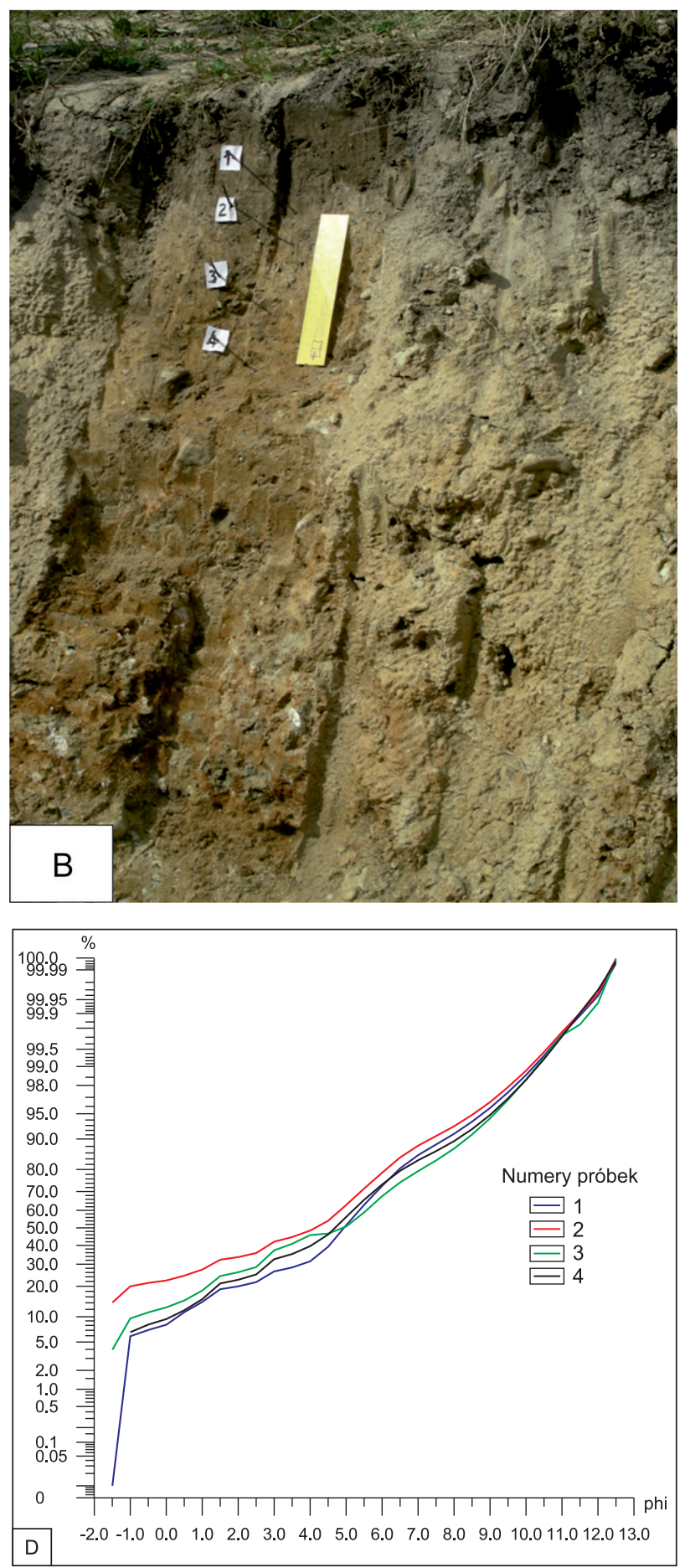

Ryc. 5. Lokalizacja stanowiska Chyżne (A) i profil badanych osadów (B) oraz profil litofacjalny osadów w stanowisku Chyżne (C) oraz ich krzywe kumulacyjne uziarnienia (D) Objaśnienia na ryc. 2A

Fig. 5. Location of the Chyżne site (A) and outcrop of study diamictions (B) and lithofacial profile of study deposit in study site (C) and their grain size composition cumulative curves (D) Explanation in the fig. $2 \mathrm{~A}$ 
spąg w wykopie nie został odsłonięty, jakkolwiek w bliskim sąsiedztwie wykopu (wcios drogowy) są wychodnie niżej zalegających żwirów, podścielonych iłami neogeńskimi. Można szacować miąższość pokrywy diamiktonowych na ok. 3 m. Struktura osadów jest masywna i są one słabo zwilgocone. Mają one jasnobrązowe zabarwienie i makroskopowo nie wykazują wyraźnego zróżnicowania pod względem uziarnienia (ryc. 5B). Jednak dużą ich domieszkę (ok. 10\%) stanowią rozproszone w materiale drobnoziarnistym otoczaki skał tatrzańskich. Na głębokości ok. 55-60 cm w osadzie drobnoklastycznym występują pojedyncze otoczaki granitowe o średnicach 3-8 cm i o różnym stopniu zwietrzenia. Na głębokości 100-120 $\mathrm{cm}$ rozciąga się poziom stosunkowo większej koncentracji (35-40\%) otoczaków granitowych o średnicach ok. 9-11 cm. Kolejną warstwę tworzą osady diamiktonowe o masywnej strukturze, w których znajduje się mniej otoczaków niż powyżej. Otoczaki są w tej warstwie głównie kwarcytowe, podrzędnie występujące otoczaki granitowe są silnie zwietrzałe. Granica pomiędzy osadami o charakterze diamiktonowym i niżej zalegającymi żwirami jest przejściowa. W całym odsłonięciu widoczne są smugi znacznej koncentracji związków żelazistych.

Osady diamiktonowe w stanowisku Chyżne są pod względem teksturalnym mułkami żwirowymi $\left(\mathrm{F}^{\mathrm{s}} \mathrm{Gm}\right)$ (ryc. 5C). Zawartość frakcji pylastej wynosi w nich przeciętnie $54 \%$, a przeciętny udział piasków to $30 \%$, żwirów 11\%, a frakcji ilastej 5\% (ryc. 5D). Mułki żwirowe w stanowisku w Chyżnem cechują się bardzo słabym wysortowaniem i mają lepto- lub platykurtyczne, a także wielomodalne rozkłady uziarnienia o ujemnej skośności (tab. 2). Na diagramie zależności średniej średnicy ziarna $(\mathrm{Mz})$ i wysortowania $\left(\sigma_{1}\right)$ zaznacza się prawidłowość polegająca na zmniejszaniu się średniej średnicy ziarna przy równoczesnym wzroście wysortowania (ryc. 6). Wyraźnie widoczne są na diagramie trzy skupienia rozmieszenia próbek: (I) przy średnich średnicach ziarna w przedziale wartości od 3,1 do 3,9 phi i wysortowa-

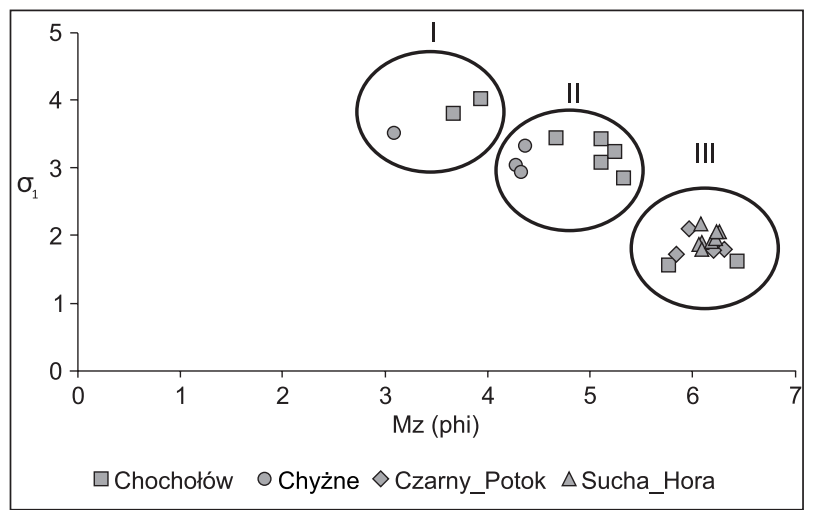

Ryc. 6. Rozmieszczenie próbek badanych osadów na diagramie zależności średniej średnicy ziarna $(\mathrm{Mz})$ i wysortowania $\left(\sigma_{1}\right)$ $\mathrm{Mz}$ - średnia średnica ziarna (phi); $\sigma_{1}$ - wysortowanie

Fig. 6. Distribution of samples of study deposits on diagram of relations between mean grain size $(\mathrm{Mz})$ and sorting coefficient $\left(\sigma_{1}\right)$

$\mathrm{Mz}$ - mean grain size (phi); $\sigma_{1}$ - sorting coefficient niu od 3,5 do 4,0, (II) przy średnich średnicach ziarna w przedziale od 4,3 do 5,3 phi i wysortowaniu od 2,2 do 3,4 i (III) przy średnich średnicach ziarna $\mathrm{w}$ przedziale od 5,8 do 6,4 phi i wysortowaniu od 1,6 do 2,2. Korelując te wartości z położeniem próbek w badanych profilach można zauważyć, że najgorzej wysortowane są osady znajdujące się w spągu profili. Posiadają one również największą średnią średnice ziarna.

\section{Interpretacja genetyczna osadów diamiktonowych}

W dotychczasowej literaturze tematycznej istnieją różne, często sprzeczne poglądy na temat pochodzenia badanych osadów gliniastych. Według hipotezy przyjmowanej przez Baumgart-Kotarbę (1991-92) osady gliniaste są pochodzenia eolicznego i pochodzą z otaczających Kotlinę Orawską pasm górskich. Proces akumulacji eolicznej zachodził według tej Autorki w warunkach klimatu zimnego. Na takie pochodzenie glin ma wskazywać ich położenie względem innych form terenu i osadów znajdujących się w Kotlinie ... pozycja tych glin wskazuje na pochodzenie eoliczne, chociaż składane byty najprawdopodobniej $w$ warunkach okresowej zmarzłoci (Baumgart-Kotarba 1991-92, s.13). Watycha (1977a, s.36) sugeruje, że badane osady mogą mieć złożoną genezę. Zakłada, że gliny te powstały w wyniku działalności procesów eolicznych i procesów spłukiwania glin ze zboczy ... w górze pokryty je gliny pylaste (deluwialno-eoliczne). Jednakże, co do glin znajdujących się w poziomie Mindel przyjmuje On fluwialne pochodzenie analizowanych osadów ... gliny te byty ostatnim osadem ze schytku glacjału południowopolskiego i poczatku interglacjału mazowieckiego przynoszonym przez potoki Czarnego Dunajca, który wówczas częściowo odplywat do Wagu (Watycha 1977a, s. 35). Podobnie Klimaszewski (1972) przyjmuje dla badanych osadów genezę złożoną - wietrzeniowo-fluwialną. Cegła (1963), który przeprowadził badania laboratoryjne osadów gliniastych występujących w Kotlinie Orawsko-Nowotarskiej stwierdza, że analizowane osady makroskopowo przypominają less, ale jednak reprezentują osad pyłowy będący zwietrzeliną skał fliszowych. W świetle danych zamieszczonych w tej pracy wydaje się jednak, że w przypadku glin w Kotlinie Orawskiej to stwierdzenie nie jest do końca prawidłowe, gdyż gliny zalegają na osadach fluwioglacjalnych, a nie bezpośrednio na fliszu. Rodzaj skał podłoża ma bardzo duże znaczenie dla przebiegu i intensywności procesów wietrzenia fizycznego i chemicznego oraz dla produkcji i składu mineralnego zwietrzeliny.

Możliwe jest również miejscowe pochodzenie osadów gliniastych. Mogą być one zwietrzeliną powstała in situ w wyniku długotrwałego wietrzenia żwirów fluwioglacjalnych w różnowiekowych stożkach Czarnego Dunajca. W plejstocenie otoczaki krystalicznych skał tatrzańskich podlegały w Kotlinie Orawskiej długotrwałemu i intensywnemu wietrzeniu, zarówno w okresach zimnych (glacjałach) jak i ciepłych (interglacjałach). Długotrwałość 
i cykliczność procesów wietrzenia mrozowego i chemicznego mogła doprowadzić do dezintegracji otoczaków skał tatrzańskich do postaci gliniastej. Na silne zwietrzenie osadów fluwioglacjalnych w starszych poziomach stożka Czarnego Dunajca zwracał uwagę Halicki (1930), a Watycha (1977a, s.34 ) napisał, że ... skaty krystaliczne takie jak granity, gnejsy, tupki krystaliczne ulegty całkowitemu rozpadowi na miat kwarcowo-skaleniowo-łyszczykowy barwy ochrowej. Ponadto potwierdzeniem skutków działania wietrzenia otoczaków granitowych z Tatr są m.in. „gliny pogranitowe” występujące na Domańskim Wierchu i w Suchej Górze (Kukulak 2001).

\section{Dyskusja}

Wyniki przeprowadzonej analizy uziarnienia nie dały jednoznacznej odpowiedzi co do genezy osadów gliniastych występujących w Kotlinie Orawskiej. Jednakże badania terenowe i wykonane analizy uziarnienia tych osadów pozwoliły wskazać środowiska, w którym następował ich transport i depozycja. Wyniki badań wskazują na bardzo podobny sposób wykształcenia osadów diamiktonowych we wszystkich stanowiskach badawczych. Badane osady gliniaste cechuje jednorodność uziarnienia zarówno w przekroju pionowym, jak i poprzecznym, zbliżona barwa oraz podobna miąższość (od 1 do $3 \mathrm{~m}$ ). Jednakże $\mathrm{w}$ rozkładzie uziarnienia tych osadów oraz w ich przestrzennym rozmieszczeniu można wskazać kilka prawidłowości.

Gliny zalegające na względnie wyższych partach stożków (stanowisko Czarny Potok i Sucha Hora, Chyżne) cechują się strukturą masywną, natomiast te które występują w obniżeniach terenu lub na terasach rzecznych posiadają nieznaczną laminację. Słabe warstwowanie glin zaznacza się tylko w würmskiej terasie Czarnego Dunajca (stanowisko Chochołów). W składzie uziarnienia osadów dominuje udział frakcji pylastej (przeciętnie od 54\% stanowisko Chyżne do 85\% stanowisko Czarny Potok) (ryc. 5D, 3D), zwłaszcza w przypowierzchniowej części profili. Analiza rozkładów uziarnienia w badanych profilach wykazała tendencję do wzrostu ku stropowi udziału frakcji grubopyłowych, maleje natomiast w tym kierunku udział frakcji piaszczystej lub też udział frakcji pylastej jest podobny w całym profilu. Zmiana proporcji frakcji piaszczystej i pylastej w badanych osadach ma odzwierciedlenie w wartości przeciętnej średniej średnicy ziarna, której wartości również maleją ku stopowi w profilach badanych glin. Przeciętna średnia średnica ziarna waha się od 3,1 phi do 6,4 phi (tab. 2).

Dominacja w osadach gliniastych frakcji pylastej nie stanowi specjalnego wyjątku kiedy porównuje się ją do zbadanych osadów gliniastych w innych regionach Karpat (Cegła 1963, Mazur 1963). Duży udział pyłu w badanych osadach sugeruje, że może on mieć zbliżoną genezę jak osady pylaste wstępujące w innych obszarach Karpat, a więc genezę eoliczną. Taką bowiem genezę przyjmuje się dla akumulacji pokryw pylastych w Kotlinie Sądeckiej
(Cegła 1963, Butrym, Zuchiewicz 1985, Alexandrowicz i in. 1991, Nawrocki, Wójcik 1995), Kotlinie Żylińskiej (Mazur 1963), w Dołach Jasielsko-Sanockich (Janiga 1971, Krysowska-Iwaszkiewicz, Wójcik 1990) oraz w Kotlinie Oświęcimskiej (Drewnik i in. 2004, Wójcik i in. 2004). Prace charakteryzujące osady lessowe i lessopodobne w południowej Polsce wykazują, że udział ziaren frakcji pylastej jest tam dominujący (ok. 35-50\%) (Zuchiewicz 1990, Butrym 1991, Gerlach i in. 1993, Kopciowska, Wójcik 1996), podobnie jak w osadach gliniastych w Kotlinie Orawskiej. Ponadto należy podkreślić, że udział frakcji pylastej w badanych osadach jest tak znaczący, że mimo zastosowania różnych podziałów frakcyjnych nie wpływa to na zmianę typu osadu. Należy jednak mieć na uwadze możliwość, że podobieństwo do lessów może być wtórne i jest wynikiem procesów postedymentacyjnych (Mycielska-Dowgiałło 2007). Pierwotnie materiał ten mógł być zwietrzeliną lokalnych skał spoistych lub aluwiów (Dylik 1952, Cegła 1963, Kukulak 2001, Wright 2007).

Nie wykluczona jest również geneza wietrzeniowa analizowanych glin. Jak wykazały badania terenowe kontakt pokryw gliniastych ze żwirami fluwioglacjalnymi stożków jest przejściowy. Ta cecha sugeruje, że badane osady mogą być końcowym produktem długotrwałego wietrzenia żwirów. Na przejściową granicę między pokrywami gliniastymi a niżej zalegającymi skałami i ich ścisły związek z procesem wietrzenia wskazuje N. Oszczypko i A. Wójcik (1984). Potwierdzeniem takiej genezy, obok glin znajdujących się na Domańskim Wierchu (Kukulak 2001), są również gliny pylaste występujące w cegielni w Bieczu (Cegła 1963) oraz gliny z okolic Jazowska (Oszczypko, Wójcik 1984). Jednakże badane osady mogą mieć inną genezę, a procesy wietrzenia tylko współuczestniczyły w powstawaniu osadów drobnoziarnistych (Pettijohn 1957, Kuenen, Pedrok 1961, Jahn 1968, Smith i in. 2002, Wright 2007) w różnym czasie ich sedymentacji i w różnych warunkach środowiska.

Przedstawione wyniki badań osadów gliniastych nie wykluczyły również jednoznacznie fluwialnego środowiska depozycji. Jeżeli uziarnienie badanych osadów przyrównywać do składu uziarnienia osadów rzek roztokowych lub mad antropogenicznych to wyniki są zbliżone. Jak wskazują badania Gębicy (2004) oraz Kalickiego i Szmańdy (2009) odsetek najdrobniejszej frakcji w aluwiach może osiągać podobne rozmiary jak w przypadku osadów gliniastych w Kotlinie Orawskiej. Za lokalnie fluwialnym środowiskiem depozycji badanych glin przemawia ponadto obecność niewyraźnego warstwowania w pokrywach gliniastych na terasach Czarnego Dunajca w Chochołowie. Porównanie poglądów Mycielskiej-Dowgiałło (1995, 2007) i Ludwikowskiej-Kędzi (2000), dotyczących interpretacji rozmieszczenia próbek na diagramie zależności $\mathrm{Mz}$ i $\sigma \mathrm{z}$ rozmieszczeniem badanych osadów gliniastych pokazuje, że analizowane osady lokują się w polu pomiędzy osadami akumulowanymi w środowisku wód stagnujących (A), o okresowej dostawie materiału w czasie wezbrań (D). Natomiast porównując 
ten sam diagram $\mathrm{z}$ diagramem rozmieszczenia próbek osadów z różnych środowisk depozycyjnych zaproponowanym przez Wysotę i in. (1996), Racinowskiego $\mathrm{i}$ in. (2003) oraz to badane osady mieszczą się w polu, w którym ulokowane były gliny morenowe oraz aluwia pozakorytowe i osady zastoiskowe.

\section{Wnioski}

Przeprowadzone badania wskazują na poligenezę osadów gliniastych w Kotlinie Orawskiej. Na obecnym etapie badań każda z wymienionych w literaturze hipotez (eoliczna, fluwialna, wietrzeniowa) jest $\mathrm{w}$ równym stopniu prawdopodobna.

Ponieważ zastosowane metody badawcze są niewystarczające dla jednoznacznego określenia genezy glin orawskich to niezbędne jest zastosowanie dla tego celu szerszego zakresu badań.

\section{Podziękowanie}

Autorka składa podziękowanie anonimowemu recenzentowi za cenne uwagi, które przyczyniły się do ulepszenia artykułu.

\section{Literatura}

Alexandrowicz S. W., Butrym J., Krysowska-Iwaszkiewicz M., Zuchiewicz W., 1991. Profil utworów lessopodobnych w Siennej koło Nowego Sącza. W: H.Maruszczak (red.) Podstawowe profile lessów w Polsce. UMCS: 124-132.

Augustowski, K., Chmielowska, D., Kukulak, J., 2013. Geologiczne uwarunkowania dynamiki procesów brzegowych rzek zachodniego Podhala. Przegląd Geologiczny 6(12): 755-763.

Baumgart-Kotarba M., 1983. Kształtowanie koryt i teras rzecznych w warunkach zróżnicowanych ruchów tektonicznych (na przykładzie wschodniego Podhala). Prace Geograficzne Instytutu Geografii i Przestrzennego Zagospodarowania PAN, 145.

Baumgart-Kotarba M., 1991-92. Rozwój geomorfologiczny Kotliny Orawskiej w warunkach ruchów neotektonicznych. Studia Geomorphologica Carpatho-Balcanica 25-26: 3-28.

Birkenmajer K., Stuchlik L., 1975. Early Pleistocene pollen-bearing sediments at Szaflary, West Carpathians, Poland. Annales Societatis Geologorum Poloniae 56(1-2): 113-146.

Birkenmajer K., 1978. Neogene to Early Pleistocene subsidence close to the Pieniny Klippen Belt, Polish Carpathians. Studia Geomorphologica Carpatho-Balcanica 12: 17-28.

Birkenmajer K., Derkacz M., Lindner L., Stuchlik L., 2008. Stanowisko 1: Szaflary Wapiennik - żwiry wodnolodowcowe zlodowacenia Mindel i starsze osady ograniczne. XV Konferencja Stratygrafia plejstocenu Polski. Plejstocen Tatr i Podhala-zlodowacenia tatrzańskie. Zakopane.

Blott S., Pye K., 2001. Gradistat: a grain size distribution and statistics package for the analysis of unconsolidated sediments. Earth Surface Processes and Landforms 26: 1237-1248.

Butrym J., Zuchiewicz W., 1985. Wyniki datowań termoluminescencyjnych osadów czwartorzędowych Kotliny Sądeckiej, Karpaty Zachodnie. Przegląd Geologiczny 33(3): 126-136.

Butrym J., 1991. Wyniki TL datowań próbek z profilu lessu w Szczyglicach. W: H.Maruszczak (red.), Podstawowe profile lessów w Polsce. UMCS: 102.

Cegła J., 1963. Porównanie utworów pyłowych kotlin karpackich z lessami Polski. Annales UMCS. sec B 18(4): 69-116.
Drewnik M., Kacprzak A., Wójcik A., Żyła M., Szeliga M., 2004. Charakterystyka utworów pyłowych w profilu Kończyce (Kotlina Oświęcimska). Biuletyn Państwowego Instytutu Geologicznego 409: 51-62.

Dylik J., 1952. Głazy rzeźbione przez wiatr i utwory podobne do lessu w środkowej Polsce. Biuletyn Państwowego Instytutu Geologicznego 67. Z badań czwartorzędu w Polsce 3: 231-332

Folk R.L., Ward W., 1957. Brazos River bar: A study in the significance of grain size parameters. Journal of Sedimentary Petrology 27: 3-26.

Gerlach T., Krysowska-Iwaszkiewicz M., Szczepanek K., Pazdur M., 1993. Nowe dane o pokrywie karpackiej odmiany lessów w Humniskach koło Brzozowa. Zeszyty Instytutu Geografii i Przestrzennego Zagospodarowania PAN 16: 1-43.

Gębica P., 2004. Przebieg akumulacji rzecznej w górnym Vistulianie w Kotlinie Sandomierskiej. Prace Geograficzne Instytutu Geografii i Przestrzennego Zagospodarowania PAN, 193.

Halicki B., 1930. Dyluwialne zlodowacenie północnych stoków Tatr. Sprawozdania Polskiego Instytutu Geologicznego 3-4: 377-534.

Jahn A., 1968. Peryglacjalne pokrywy stokowe Gór Izerskich i Karkonoszy. Opera Corcontica 5: 9-25.

Janiga S., 1971. Deflacyjna rola wiatru w kształtowaniu rzeźby Beskidu Niskiego. Przegląd Geograficzny XLII(3): 427-433.

Kalicki T., Szmańda J., 2009. Litologia, wiek i geneza mad wiślanych w Kotlinie Sandomierskiej i Kotlinie Toruńskiej. W: A.Kostrzewski, R.Paluszkiewicz (red.), Geneza, litologia i stratygrafia utworów czwartorzędowych, 5, Seria Geografia 88: 165-186.

Klimaszewski M., 1967. Polskie Karpaty Zachodnie w okresie czwartorzędowym. W: Czwartorzęd Polski: 431-497.

Klimaszewski M., 1972. Karpaty Wewnętrzne. W: Geomorfologia Polski, PWN, Warszawa: 25-52.

Kondracki J., 2000. Centralne Karpaty Zachodnie W: Geografia regionalna Polski. PWN, Warszawa: 351-371.

Kopciowska B., Wójcik A., 1996. Minerały ciężkie w utworach lessopodobnych w profilu Nowy Sącz - Załubińcze (Kotlina Sądecka). Biuletyn PIG, 374: 41-57.

Krysowska-Iwaszkiewicz M., Wójcik A., 1990. Wyniki datowań późnoplejstoceńskich stokowych pokryw gliniastych w Jedliczach (Doły Jasielsko-Sanockie). Studia Geomorphologica Carpatho-Balcanica 24: $65-84$.

Książkiewicz M., 1972. Karpaty. Tektonika, 3. Budowa geologiczna Polski. PWN, Warszawa.

Kuenen Ph.H., Pedrok W.G. 1961. Experimental abrasion 5: Frosting and defrosting of quartz grains. Journal of Geology 70: 648-658.

Kukulak J., 2001. Weathering of gravels in the Czarny Dunajec alluvial cone in Podhale Polish Carpathians. Quastiones Geographicae 21: 69-78.

Lindner L., 1994. Jednostki stadialne i interstadialne ostatniego zlodowacenia (Wurm, Vistulian) w Tatrach polskich i na Podhalu. Acta Universitatis Nicolai Copernici, Geografia, 27: 59-73.

Ludwikowska-Kędzia M., 2000. Ewolucja środkowego odcinak doliny rzeki Belnianki w późnym glacjale i holocenie. Wydawnictwo Akademickie Dialog, Warszawa: 1-182.

Nawrocki J., Wójcik A., 1995. Lithology and stratigraphy of Pleistocene loess-like deposits in the Załubińcze section. Geological Quarterly 39: 121-143.

Mazur E., 1963. Žilinská kotlina a pril'ahlé pohoria. Vyd. Slovenskiej Akad. Vied, Bratislava.

Mycielska-Dowgiałło E., 2007. Wybrane cechy teksturalne i ich wartość interpretacyjna W: E.Mycielska-Dowgiałło, J.Rutkowski (red.), Badania cech teksturalnych osadów czwartorzędowych i wybrane metody oznaczania ich wieku. Wydawnictwo Szkoły Wyższej Przymierza Rodzin, Warszawa: 95-181.

Obidowicz A., 1988. The Puścizna Rękowiańska raised bog. W: Lateglacial and Holocene Environmental Changes Vistula Basin 1988. Excursion Guide Book - Symposium, Cracow 15-21 June 1988. Wydawnictwa Akademii Górniczo-Hutniczej, Kraków: 87-90.

Obidowicz A., 1990. Eine Pollenanalytische und Moorkundliche Studie zur Vegetations - geschichte des Podhale Gebietes (West-Karpaten). Acta Palaeobotanica 30(1-2): 147-219.

Oszczypko N., Wójcik A., 1984. Utwory czwartorzędowe Beskidu Sądeckiego między Wietrznicą a Jazowskiem. Biuletyn Państwowego Instytutu Geologicznego 340(23): 90-109. 
Pettijohn F.J., 1957. Sedimentary rock. Harper and Brothers, New York: $1-718$.

Racinowski R., Szczypek T., Wach T., 2001. Prezentacja i interpretacja wyników badań uziarnienia osadów czwartorzędowych. Skrypt Uniwersytetu Śląskiego. Katowice: 1-146.

Smith B.J., Wright J.S., Whalley W.B., 2002. Sources of non-glacial, loess-size quartz silt and the origins of "desert loess". Earth Science Reviews 59: 1-26.

Szmańda J.B., 2011. Zapis warunków depozycji w uziarnieniu aluwiów pozakorytowych. Landform Analysis, 18: 3-97.

Watycha L., 1973. Utwory czwartorzędowe w otworze wiertniczym Wróblówka na Podhalu. Kwartalnik Geologiczny 17(2): 335-347.

Watycha L., 1976. Neogen niecki orawsko-nowotarskiej. Kwartalnik Geologiczny 20(3): 575-586.

Watycha L., 1977a. Objaśnienia do Szczegółowej Mapy Geologicznej Polski 1:50 000. Arkusz Jabłonka (1047). Państwowy Instytut Geologiczny, Warszawa: 30-43.
Watycha L., 1977b. Objaśnienia do Szczegółowej Mapy Geologicznej Polski 1:50 000. Arkusz Czarny Dunajec (1048). Państwowy Instytut Geologiczny, Warszawa: 1-102.

Wójcik A., Nawrocki J., Nita M., 2004. Plejstocen w profilu Kończyce (Kotlina Oświęcimska) - analiza genezy i wieku na tle schematów podziału stratygraficznego czwartorzędu. Biuletyn Państwowego Instytutu Geologicznego, 409: 5-50.

Wright J.S., 2007. An overview of the role of weathering in the production of quartz silt. Sedimentary Geology 202: 337-351.

Wysota W., Lankauf K.R., Molewski P., Szmańda J., 1996. Sedymetologia interstadialnej serii rzecznej (Rzęczkowo) zlodowacenia wisły (vistulian) odsłoniętej w płd.-zach. Krawędzi Wysoczyzny Chełmińskiej. Acta Universitatis Nicolai Copernici, Geografia, 28: 39-63.

Zieliński T., Pisarska-Jamroży M., 2012. Jakie cechy litologiczne warto kodować, a jakie nie? Przegląd Geologiczny 60(7): 387-397.

Zuchiewicz W., 1990. Utwory czwartorzędowe Pogórza Rożnowskiego w Karpatach Zachodnich. Przegląd Geologiczny 38(7-8): 307-315. 